\title{
Estimating the potential water reuse based on fuzzy reasoning
}

\author{
Giovana Almeida ${ }^{\mathrm{a}, *}$, José Vieira $^{\mathrm{b}}$, Alfeu Sá Marques ${ }^{\mathrm{a}}$, Asher Kiperstok ${ }^{\mathrm{c}}$, Alberto Cardoso ${ }^{\mathrm{d}}$ \\ ${ }^{a}$ University of Coimbra, Dept. of Civil Engineering, Pólo II, Coimbra, Portugal \\ ${ }^{\mathrm{b}}$ University of Minho, Dept. of Civil Engineering, Braga, Portugal \\ ${ }^{\mathrm{c}}$ Federal University of Bahia, Polytechnic, Dept. of Environmental Engineering, Rua Aristides Novis 02, Federacão, Salvador, BA, Brazil \\ ${ }^{\mathrm{d}}$ University of Coimbra, Dept. of Informatics Engineering, Pólo II, Coimbra, Portugal
}

\section{A R T I C L E I N F O}

\section{Article history:}

Received 11 January 2013

Received in revised form

27 June 2013

Accepted 30 June 2013

Available online 20 July 2013

\section{Keywords:}

Potential water reuse

Water shortage

Fuzzy logic

Climate change

\begin{abstract}
A B S T R A C T
Studies worldwide suggest that the risk of water shortage in regions affected by climate change is growing. Decision support tools can help governments to identify future water supply problems in order to plan mitigation measures. Treated wastewater is considered a suitable alternative water resource and it is used for non-potable applications in many dry regions around the world. This work describes a decision support system (DSS) that was developed to identify current water reuse potential and the variables that determine the reclamation level. The DSS uses fuzzy inference system (FIS) as a tool and multi-criteria decision making is the conceptual approach behind the DSS. It was observed that water reuse level seems to be related to environmental factors such as drought, water exploitation index, water use, population density and the wastewater treatment rate, among others. A dataset was built to analyze these features through water reuse potential with a FIS that considered 155 regions and 183 cities. Despite some inexact fit between the classification and simulation data for agricultural and urban water reuse potential it was found that the FIS was suitable to identify the water reuse trend. Information on the water reuse potential is important because it issues a warning about future water supply needs based on climate change scenarios, which helps to support decision making with a view to tackling water shortage.
\end{abstract}

(C) 2013 Elsevier Ltd. All rights reserved.

\section{Introduction}

Planned water reuse projects are identified around the world, however, there are circumstances where alternative water resources are only sought after emergency situations. Water shortage causes a substantial damage considering the losses of crops and livestock in many countries, and poses a risk to human health when is not enough for drink and cleaning or when contaminated water sources are used. Identification and discussion of the factors that drive risks on water supply security is important for decision making systems development and useful to manage water resources efficiently.

Global warming, water consumption and population growing trends suggest a worsening in water shortages (World Water Assessment Programme, 2009). The trends towards persistent drought increase constitute a warning about safety and security of water supply. Results of simulations based on global climate

\footnotetext{
* Corresponding author.

E-mail addresses: giovanaalmeida@dec.uc.pt, giovana.almeida@gmail.com (G. Almeida), jvieira@civil.uminho.pt (J. Vieira), jasm@dec.uc.pt (A.S. Marques), asher@ufba.br (A. Kiperstok), alberto@dei.uc.pt (A. Cardoso).
}

models (GCMs) show that there will be significant increases in consecutive dry days (IPCC, 2012). The trend towards reduced precipitation and/or increased evapotranspiration, higher than medium confidence level, is that droughts will intensify in the $21 \mathrm{st}$ century. It applies to southern Europe and the Mediterranean region, central Europe, Central North America, Central America, northeastern Brazil, and southern Africa (Dai, 2011).

Besides climate change, population growth in megacities also increases water access vulnerability in densely populated regions such as Beijing (China), Tokyo (Japan) and Delhi (India). Water shortage in these regions will become more frequent because of higher water consumption and water stress intensification (Bates et al., 2008). The water consumption may decrease when water price increases (Fig. 1), however, higher water tariffs are a limitation to water access in some regions. A prolonged drought is one of the factors that may increase the price of water. For instance, San Diego (USA) and Barcelona (Spain) have already imported water from regional wholesale suppliers and by boat transport during droughts, which means higher payments for raw water (Walton, 2011).

The scenarios presented for water availability have shown the need of future alternative sources of supply necessities. In regions 

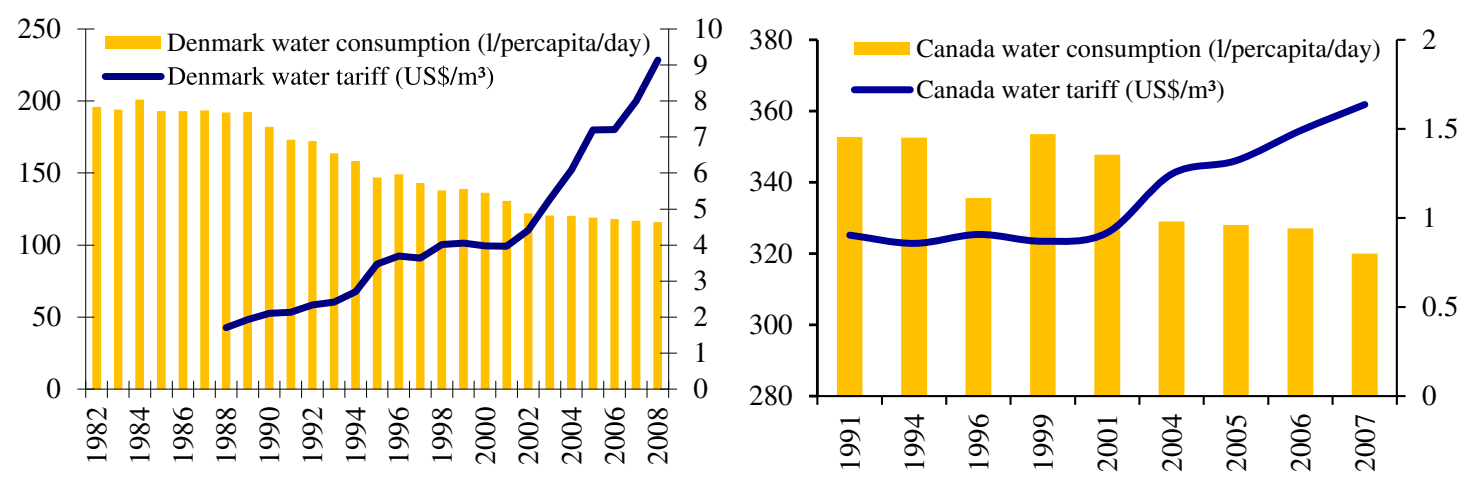

Fig. 1. Trends in water consumption and tariff: Denmark (DANVA, 2011) and Canada (AECOM and NRC, 2009).

with high scarcity the treated wastewater may be an important resource. Irrigation is the main activity related to treated wastewater use since it consumes most water (AQUASTAT/FAO, 2012). Urban water reclamation for golf course irrigation, toilet flushing and street cleansing is also considered, although water reuse for artificial aquifer recharge, industrial cooling and irrigation in restricted areas are better accepted.

Researchers worldwide are developing water management systems in order to solve many water supply problems. The AQUAREC Project has developed integrated concepts for reusing upgraded wastewater in European countries. The decision support software for water treatment for reuse with Network Distribution WTRNet developed within the AQUAREC Project provides an integrated framework for the treatment and distribution aspects of the optimization of water reuse and the selection of end-users (Joksimovic et al., 2008). Other authors (e.g. Zarghami et al., 2007; Tkach and Simonovic, 1997; Hyde et al., 2005) propose multi-criteria decision making (MCDM) tools to solve various water management problems in light of the flexibility needed to deal with environmental data. The evaluation of future alternative of water resources necessities depends on the adaptive management tools development. The environmental model, which aims to identify those necessities, must take into account some aspects related to water stress.

Realizing the importance of tools that support water management decisions, we present in this paper the rationale and results of a fuzzy inference system (FIS) that estimate the potential for regional reuse using factors (i.e. drought, water exploitation, water uses, wastewater treatment rate among others) considered relevant to the perceived need for reuse. The main objective of this manuscript is to present the agricultural and urban water reuse potential model and results considering a dataset for 155 regions and 185 cities. It also aims to support decision makers, providing insights to tackle water shortage and to promote discussions about factors that incentive water reuse.

\section{Methodology}

The identification of the main types of recycled water use was the first step in this research work. Taking into account the largest water reclamation users (Europe, Israel, California, Japan and Australia) more than a half of recycled water is used for agricultural purpose. Urban use is the second most used type of recycled water in these regions, immediately followed by ground water recharge (Table 1).

Due to agricultural and urban water reuse tendency, factors that stimulate these two types of reuse were considered when developing the system. In this work the urban water reuse was considered for watering (gardens, parks, landscapes, etc.), washing (streets, vehicles, public monuments, etc.), firefighting and toilet flushing in metropolitan public areas. The crops irrigation was considered for agricultural water reuse. Other urban reclamation options were not considered because it was observed that governments' stimulation is usually responsible for a large scale water reuse. In addition, some industrial, residential and commercial water reuse is related to private incentives that are driven by economic concerns rather than water conservation reasons.

In the second phase, the main factors that encourage agricultural and urban water reuse were identified. These factors were considered as features in the proposed system. The features used to analyse agricultural water reuse potential were the drought, the water exploitation index (WEI) and the ratio between agricultural water use and urban water supply use. For urban water reuse potential, the features were WEI, drought, demographic density and wastewater treatment rate. 155 regions were selected from around the world to analyze the features that drive the agricultural water reuse in order to design the water reuse potential model. For urban water reuse 185 cities were surveyed. The regions and cities were chosen taking into account its water reclamation relevance and available data. Other regions firstly selected due to its water reuse relevance were left out of this work due to difficulties in finding

Table 1

Water reuse by type.

\begin{tabular}{|c|c|c|c|c|c|c|c|}
\hline \multirow[t]{2}{*}{ Regions } & \multicolumn{7}{|c|}{ Water reuse $\left(\mathrm{Mm}^{3} / \mathrm{a}\right)$} \\
\hline & Total & Agricultural & $\begin{array}{l}\text { Ground water } \\
\text { recharge }\end{array}$ & Industrial & Ecologic use & Urban use & Domiciliary \\
\hline Europe and Israel & 963 & 674 & 164 & 39 & 48 & 39 & 0 \\
\hline California-EUA & 434 & 213 & 61 & 22 & 56 & 82 & 0 \\
\hline Japan & 206 & 16 & 0 & 16 & 66 & 78 & 29 \\
\hline Australia & 166 & 50 & 0 & 66 & 5 & 40 & 5 \\
\hline Total $\left(\mathrm{Mm}^{3} / \mathrm{a}\right)$ & 1769 & 953 & 224 & 143 & 175 & 239 & 34 \\
\hline Percentage (\%) & & 54 & 13 & 8 & 10 & 14 & 2 \\
\hline
\end{tabular}

Source: Adapted from: Report on integrated water reuse concepts (Wintgens and Hochstrat, 2006). 
reliable data. Environmental companies and government statistics were the preferred data sources. A partial dataset is illustrated in Table 2 and the full dataset can be accessed at www.dec.uc.pt/ $\sim$ giovanaalmeida/Dataset.xlsx. The data on regions and cities were evaluated separately in order to identify local characteristics.

The fuzzy logic toolbox of Matlab ${ }^{\circledR}$ was used to build the fuzzy inference system (FIS) and a Simulink model was developed to process the data. Explanations about the features choices and dataset can be found in Section 2.1. The development process of the decision support system (DSS) is described in Section 2.2.

\subsection{Dataset evaluation for water reuse potential estimation}

Analyzing the data of 155 regions (Fig. 2) it is observed that persistent drought and the WEI are the important indicators for the need to find alternative water supply resources. This information confirms that the lack of water is the main impetus for water reuse choice. Assuming that the urban water supply will produce wastewater that could be recovered to satisfy irrigation demands, it is considered that the higher the ratio between these two parameters (water supply volume and irrigation demands) the greater the agricultural water reuse potential.

Considering the set of 183 cities surveyed, it is observed that the high water consumption in densely populated cities is the trigger for pressure on water availability. Correlations between water reuse and the water exploitation (WEI) indicate that urban water supply problems due to scarcity are more sensitive to high WEI (correl. $=0.70)$ than drought (correl. $=0.40$ ). From the dataset considered it can be seen that cities whose WEI is above $40 \%$ have a high urban water recycle tendency, as depicted in Fig. 3.

It is important to identify regional features' variables through micro monitoring so as to support decision making, and it is also a constraint for the adaptive management required under conditions of climate change. The variety of microclimates and local characteristics applying to an extensive area could underestimate the real scarcity situation. More information about dataset statistical analysis can be seen at supporting information (Appendix A).

\subsection{Fuzzy inference system model for water reuse potential}

The decision support system (DSS) uses FIS as a tool and the conceptual approach behind the DSS is multi-criteria decision making (MCDM). Linguistic subjective variables are converted into numbers through fuzzy sets, and fuzzy logic uses logical operators to manipulate these numbers mathematically. MCDM can deal with many real life problems, but there is a special challenge when dealing with environmental data, because there is very high uncertainty (Triantaphyllou et al., 1998). One way to classify MCDM methods is according to the kind of data they use. The main types are: deterministic, stochastic, and fuzzy MCDM methods. The fuzzy logic systems use formal models of reasoning (IF-THEN models) to approximate reasoning under uncertainty (Zadeh, 1965). The uncertainty of the datasets used in this research (i.e. drought, WEI, water consumption, water tariff, etc.) meant that the fuzzy logic method was considered a suitable option (Ludwig et al., 2004).

The membership function in fuzzy logic can be represented by four basic shapes: triangular, trapezoidal, sigmoid and Gaussian. These shapes give an indication of how the grade of memberships varies along the $y$-axis. In this research a Gaussian curve with uncertain mean (bell-shape) was chosen, because its responses could fit with the common perception of how environmental conditions change (Fig. 4).

This membership function is suitable to characterize the antecedents and consequents in approximate reasoning (IF-THEN models), in situations where the rules deal with words or uncountable concepts (Shepard, 2005).

Table 2

Sample of agriculture data.

\begin{tabular}{|c|c|c|c|c|c|c|c|c|c|c|c|c|}
\hline Region & $\begin{array}{l}\text { Water supply } \\
\text { use }\left(\mathrm{Mm}^{3} / \mathrm{y}\right)\end{array}$ & Ref. $^{a}$ & $\begin{array}{l}\text { Agric. use } \\
\left(\mathrm{Mm}^{3} / \mathrm{y}\right)\end{array}$ & Ref. $^{a}$ & $\begin{array}{l}\text { AGR/UWS } \\
\text { ratio }\end{array}$ & $\begin{array}{l}\text { WEI } \\
\text { region }\end{array}$ & Ref. $^{a}$ & $\begin{array}{l}\text { Drought } \\
\text { region }\end{array}$ & Ref. $^{a}$ & $\begin{array}{l}\% \text { ww recycling } \\
\text { for agric. }\end{array}$ & Ref. $^{a}$ & Clas. \\
\hline Mendoza (AR) & 271.15 & 1 & 4299.36 & 19 & 15.86 & 35 & $22 \& 23$ & 6 & $30 \& 31$ & 60 & 14 & 5 \\
\hline Queensland (AU) & 340.20 & 2 & 2144.30 & 2 & 6.30 & 40 & $22 \& 23$ & 10 & $30 \& 31$ & 6.3 & 2 & 3 \\
\hline Ceará (BR) & 232.50 & 3 & 1426.00 & 20 & 6.13 & 20 & 24 & 5 & $30 \& 31$ & 0.6 & 35 & 1 \\
\hline Alberta (CA) & 379.12 & 4 & 498.50 & 21 & 1.31 & 23 & 25 & 5 & $30 \& 31$ & 2 & $33 \& 34$ & 2 \\
\hline British Columbia (CA) & 461.92 & 4 & 233.24 & 21 & 0.50 & 10 & 25 & 0 & $30 \& 31$ & 2 & $33 \& 34$ & 2 \\
\hline Beijing $(\mathrm{CN})$ & 126.75 & 5 & 1235.50 & 5 & 0.97 & 45 & $22 \& 23$ & 7 & $30 \& 31$ & 25 & 36 & 5 \\
\hline Tianjin (CN) & 419.14 & 6 & 1217.71 & 6 & 2.91 & 20 & $22 \& 23$ & 5 & $30 \& 31$ & 3.2 & 6 & 2 \\
\hline Crete (GR) & 34.43 & 7 & 676.64 & 7 & 19.65 & 24 & $26 \& 27$ & 5 & $32 \& 31$ & 20 & $26 \& 37$ & 5 \\
\hline Israel & 685.00 & 8 & 1016.00 & 8 & 1.48 & 109 & $23 \& 28$ & 9 & $30 \& 31$ & 67 & 37 & 5 \\
\hline Delhi (IN) & 956.30 & 9 & 606.09 & 10 & 0.63 & 80 & $22 \& 23$ & 7 & $30 \& 31$ & 80 & 38 & 5 \\
\hline Isole (IT) & 798.00 & 11 & 2191.00 & 12 & 2.75 & 30 & $23 \& 27$ & 6 & $32 \& 31$ & 9.21 & 35 & 4 \\
\hline Jordan (JO) & 54.37 & 13 & 226.25 & 13 & 4.16 & 100 & $22 \& 23$ & 9 & $30 \& 31$ & 100 & 39 & 5 \\
\hline Valey of Mexico (MX) & 1261.0 & 14 & 1419.00 & 14 & 1.13 & 45 & $22 \& 23$ & 7 & $30 \& 31$ & 86 & 40 & 5 \\
\hline Algarve (PT) & 52.01 & 7 & 247.12 & 15 & 4.75 & 45 & $26 \& 27$ & 5 & $32 \& 31$ & 2 & 41 & 2 \\
\hline South (KR) & 698.62 & 15 & 5198.20 & 15 & 7.44 & 10 & $22 \& 23$ & 0 & $30 \& 31$ & 0.03 & 42 & 1 \\
\hline Andalusia (ES) & 532.16 & 16 & 4579.25 & 7 & 8.61 & 45 & $23 \& 27$ & 5 & $32 \& 31$ & 12 & 43 & 5 \\
\hline Valencia (ES) & 342.83 & 16 & 2056.835 & 7 & 6.00 & 60 & $23 \& 27$ & 8 & $32 \& 31$ & 26.72 & 43 & 5 \\
\hline Tunisia (TN) & 348.10 & 7 & 2110.4 & 17 & 6.06 & 57 & $23 \& 28$ & 5 & $30 \& 31$ & 25 & 17 & 5 \\
\hline California (USA) & 395.16 & 18 & 42141.1 & 18 & 106.64 & 35 & $23 \& 29$ & 8 & $30 \& 31$ & 36 & 44 & 5 \\
\hline Florida (USA) & 274.95 & 18 & 5927.38 & 18 & 21.56 & 30 & $23 \& 29$ & 5 & $30 \& 31$ & 9 & 44 & 4 \\
\hline New Mexico (USA) & 43.38 & 18 & 3951.59 & 18 & 91.08 & 50 & $23 \& 29$ & 5 & $30 \& 31$ & 1 & 44 & 1 \\
\hline Texas (USA) & 181.00 & 18 & 11923.8 & 18 & 65.88 & 42 & $23 \& 29$ & 4 & $30 \& 31$ & 3.5 & 44 & 2 \\
\hline
\end{tabular}

AGR/UWS ratio: agriculture and urban water supply ratio.

WEI: water exploitation index.

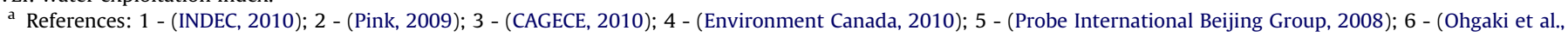

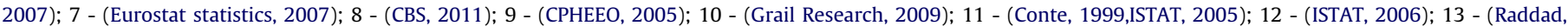

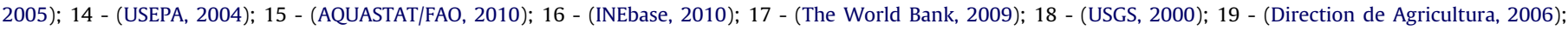

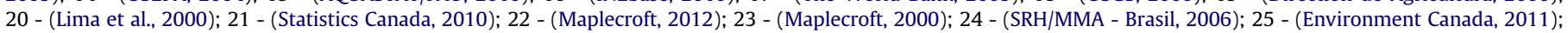

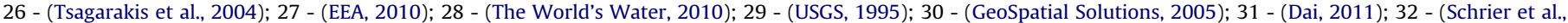

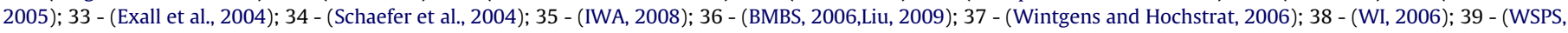
2004); 40 - (Peasey et al., 2000); 41 - (Monte, 2010); 42 - (Park, 2010); 43 - (INE, 2010); 44 - (Hermanowicz, 2006); 45 - (UDWR, 2005). 


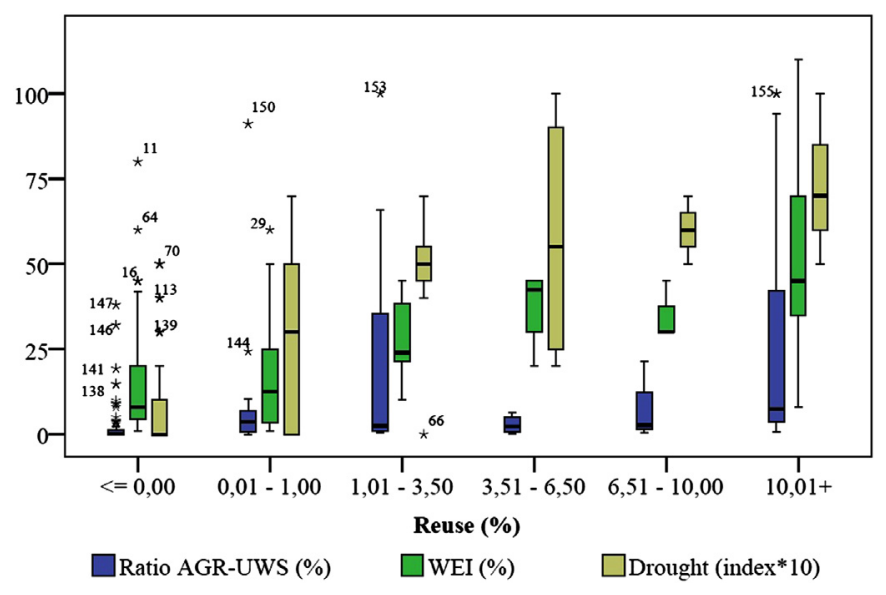

Fig. 2. Evaluation of 155 regions' features that may drive agricultural water reuse. Source: (www.dec.uc.pt/ giovanaalmeida/Dataset.xlsx).

Model building process of the agricultural and urban water reuse potential FIS employed the dataset information (Section 2.1) in order to identify the features and variables of the membership function.

\subsubsection{Model of agricultural water reuse potential}

The identification of the data and the range for each membership function according to the features' variables (Fig. 5) was necessary to build the FIS for agricultural water reuse potential. A Simulink ${ }^{\circledR}$ model was used for data processing purposes.

A drought index is a single number that makes the data easily understanding for decision making. The negative values indicate less rainfall while positive values indicate excessive rainfall. Meteorological agencies around the world use different indexes to manage the drought, which makes it difficult to choose only one index to express the drought severity level in a region. In this research a new feature based on the three most common drought indices (SPI - Standardized Precipitation Index, PDSI - Palmer Drought Severity Index and WASP - Weighted Anomaly Standardized Precipitation) was developed (Table 3), thereby creating the range of membership function variables (Fig. 6).

Understanding a region's water dynamics is fundamental to developing an effective local strategy to adapt to climate change. The WEI is a feature that measures the water stress resulting from

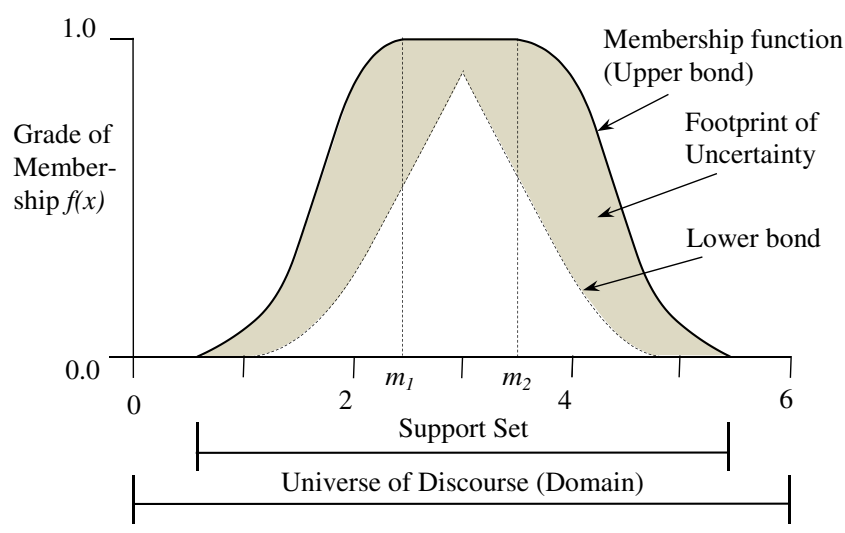

Fig. 4. Gaussian curve with uncertain mean (bell shape). Adapted from (Shepard, 2005).

the ratio between the annual water withdrawal and water availability (Brown and Matlock, 2011). Values above 20\% indicate that a country has medium-high water stress and below $10 \%$, the water stress is considered low (OECD, 2003). The OECD classification was used to build the range of the membership function variables (Table 4).

The feature representing the AGR-UWS ratio was created to identify the representativeness of agricultural water use in a region. For this, a set of membership functions for AGR-UWS ratio was built up (Table 5). This classification was based on authors' estimations using the AGR-UWS ratios and levels of agricultural reuse in the 155 regions considered (dataset information).

Even though untreated wastewater use in agriculture could present a high risk to human health, some regions make large use of sewerage effluent, pumping it directly on the crops (Mapanda et al., 2005,Maldonado et al., 2008) because of its low wastewater treatment rate. A high wastewater reuse in regions with low treatment rate and the low level of reuse in regions with high treatment rate is noticeable, and this lowers the correlation between the agricultural water reuse and wastewater treatment rate. This is why the "wastewater treatment rate" was not considered a feature for the agricultural water reuse system.

The output classification for agricultural water reuse potential was developed based on the percentage of wastewater recycling for agriculture. It was considered that values above 6.5\% express a high agricultural water reuse and below 3.5\% the reclamation is low.

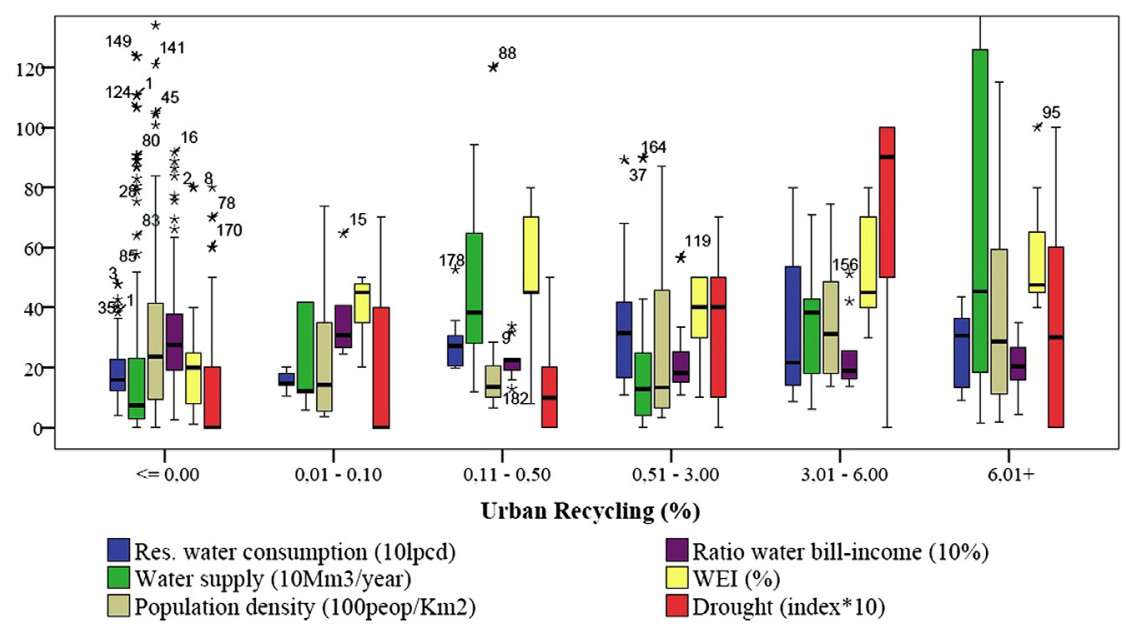

Fig. 3. Evaluation of 183 cities' features that may drive urban water reuse. Source: (www.dec.uc.pt/ giovanaalmeida/Dataset.xlsx). 


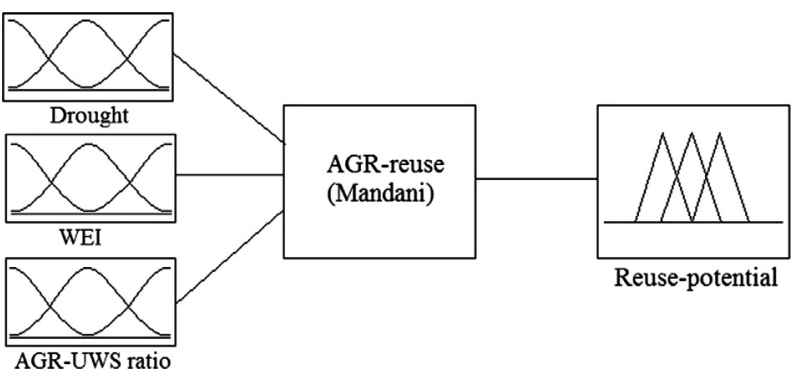

Fig. 5. Agricultural water reuse potential FIS.

Table 6 presents the classification and Fig. 7 shows the membership function configuration.

Ninety-six rules were created to correlate all the fuzzy sets with the relevant membership function. The logical operator AND (Table 7) was used to create the rules in order to get the minimum value that represents the intersection between two fuzzy sets (min $(A, B)$ or $A \wedge B$ ). The center of gravity method was used for defuzzification.

\subsubsection{Model of urban water reuse potential}

The features used for the urban water reuse potential were: scarcity-level, demographic density and wastewater treatment rate. The scarcity-level feature values result from the output of a scarcity-level FIS, taking two Fuzzy sets: WEI and drought (Fig. 8).

The scarcity-level FIS was devised in order to give an additional weight to the WEI feature. It was observed in dataset analyses that the WEI is more related to urban water reuse than drought (Fig. 3) The concepts behind the WEI and drought features are the same as those used for agricultural water reuse, but the rules for scarcitylevel took the significance of the WEI values into account. The output classification for the FIS scarcity-level is shown in Table 8 and Fig. 9.

The urban water reuse FIS uses the data of scarcity-level FIS output as input data, but the variable for scarcity-level input was built with a different range (Table 9). The range was changed to simplify the system, using fewer rules without loss of accuracy of the output results. The method used to define the range of the variables took the relation between the scarcity values and wastewater reuse rate into account. It was observed that most reuse cases occur for a scarcity-level greater than 7. Fewer cases were found for scarcity levels 5 to 7 , and no cases were detected for 0 to 5 (Fig. 10).

In addition to human water consumption, urban water infrastructure is needed that can support an overpopulated city (with hospitals, schools, parks, gardens, streets, etc.) that demands a large amount of water resources for cleaning and watering. It is thus assumed that a densely populated city with scarcity problems will have greater urban water reuse potential. To identify the urban water reuse potential, the range of demographic density variables

Table 3

Drought severity index features.

\begin{tabular}{lllll}
\hline $\begin{array}{l}\text { Drought severity } \\
\text { features }\end{array}$ & $\begin{array}{l}\text { Drought } \\
\text { variables }\end{array}$ & SPI & PDSI & WASP \\
\hline Near normal & 0 to 1.99 & 0.50 to -0.50 & 0.49 to -0.49 & 1 to -1 \\
Abnormally dry & 2 to 2.99 & -0.51 to -0.79 & -0.50 to -0.99 & -1 to -1.5 \\
Moderately dry & 3 to 3.99 & -0.80 to -1.29 & -1 to -1.99 & -1.5 to -2 \\
Severely dry & 4 to 5.99 & -1.30 to -1.59 & -2 to -2.99 & -2 to -3 \\
Extremely dry & 6 to 7.99 & -1.60 to -1.99 & -3 to -3.99 & -3 to -4 \\
Exceptionally dry & 8 to 10 & -2 or less & -4 or less & -4 or less \\
\hline
\end{tabular}

Source: (Hayes, 1999)

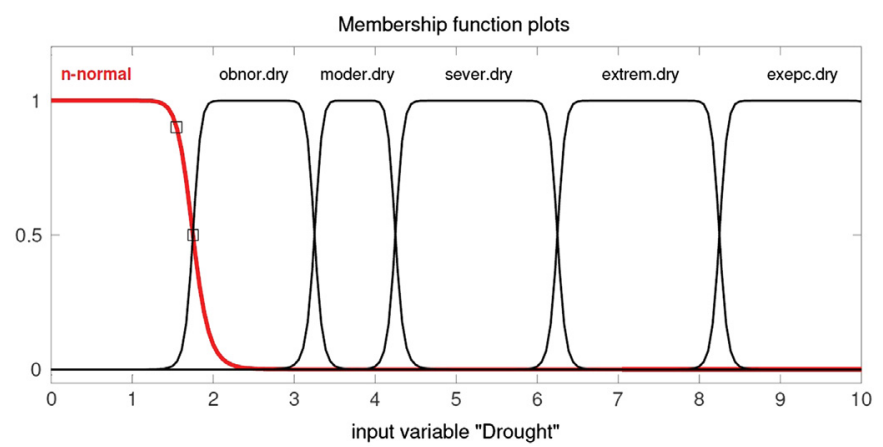

Fig. 6. Membership function of input variable drought.

considered in this research was set with the correlation between population data and level of urban reuse in 183 cities (Table 10).

Since human health requirements are related to the wastewater treatment rate, this parameter is important for establishing urban water reuse potential. Table 11 identifies the wastewater treatment rate range considered in this work.

The output classification was created based on the real percentage of urban wastewater recycling. The same method was used for data analysis as for agricultural water reuse potential. The classification of urban water reuse potential expresses the level of water reuse in a city. It was considered that values above $3 \%$ express high urban water reuse and below $0.5 \%$ the reclamation is low. The differences between agricultural and urban wastewater recycling ranges indicate the imbalance of water reuse potential for each use. The water reuse potential for agriculture is greater than for urban water reclamation because of the large demand for irrigation. Moreover, wastewater quality requirements for irrigation are lower than for urban uses, and so a less complex treatment system is needed (Table 12).

Thirty-six rules were created to correlate all the fuzzy sets and the relevant membership function. The logical operator AND was applied in order to obtain the minimum value that represents the intersection between two fuzzy sets (min $(A, B)$ or $A \wedge B$ ). The center of gravity method was used for defuzzification.

\section{Results and discussion}

The developed models were tested in order to verify if they simulate the real situations described by dataset. The results indicate that the selected features' variables provide a suitable value for the reuse potential level. The final models are a result of several iterations and adjustments of variables ranges in order to get the best data fit. The output of the final model for agricultural water reuse potential match with the dataset classification in $90 \%$ of the cases (Fig. 11).

The major difference between classification and simulation values was in the New Mexico (USA) data. Whereas the environmental characteristics of the region indicate a high water reuse resulting in a high simulation value, the classification value does

Table 4

Water Exploitation Index features.

\begin{tabular}{ll}
\hline Water stress features & WEI variables $(\%)$ \\
\hline High & $>40$ \\
Medium-high & $>20$ and $\leq 40$ \\
Moderate & $>10$ and $\leq 20$ \\
Low & $\leq 10$ \\
\hline
\end{tabular}

Source: (OECD, 2003) 
Table 5

AGR-UWS ratio variables.

\begin{tabular}{ll}
\hline Features & AGR-UWS ratio variables \\
\hline Very-high & $>4.0$ \\
High & $1.5-4.0$ \\
Average & $0.5-1.49$ \\
Low & $<0.5$ \\
\hline
\end{tabular}

not. However, regions near to New Mexico and with similar characteristics, such as Arizona and Utah, have high water reuse. Research has shown (Hermanowicz, 2006) that the variations in water reuse in different parts of the USA can be explained by the variability of water availability, as measured by the rainfall variability index. The rainfall variability index is calculated by the coefficient of variation combined with the Hurst exponent. It would be quite difficult to use this method to calculate the rainfall variability index for all the regions considered in this work, so the variability of water supply was therefore not measured. However, would be interesting to use this feature in a narrower scope to estimate water reuse potential.

Differences between classification and simulation were also found for Auvergne (FR), Maharastra (IN), southern Italy, Alentejo (PT) and Colorado (USA). These differences could be explained by specific situations, including the uncertain values between variables, adjustments of variables, inaccurate data and evaluation errors. Although there are some imprecise output data, the general results can be regarded as a good indicator for agricultural reuse potential.

The data processing results for the FIS for urban water reuse potential indicate that the output values had a good relation with the reuse classification values (Table 11 ). About $85 \%$ of the output data match the classification (Fig. 12).

The fit of the simulation values for urban water reuse potential FIS with the classification values was less good than it was for the agricultural water reuse FIS. The complexity of the urban environment is a challenge to finding suitable features for water reuse potential. The features used in the urban FIS were considered to represent the worldwide data best, but regional contexts could require some adjustment of the features.

Significant differences were found between the classification and simulation values in the three Japanese cities of Sapporo, Fukuoka and Osaka. These results can be explained by specific characteristics that contribute to water shortage in Japan such as, localized drought, high water consumption due to overpopulated cities, pollution and geographical conditions. Despite average rainfall in Japan being $1700 \mathrm{~mm}$, which is twice the world average, the annual per capita rainfall is about $1 / 4$ of the world average $\left(5100 \mathrm{~m}^{3}\right)$, because it is a small strip of land with overpopulated cities, which further aggravate water supply problems (Tajima et al., 2002). Japan has also experienced severe droughts, for example, 1939 in Lake Biwa, 1964 during the Tokyo Olympic Games, 1967 in Nagasaki, 1973 in Takamatsu, 1978 in Fukuoka (with rationing of

\section{Table 6}

Agricultural water reuse potential classification.

\begin{tabular}{lll}
\hline $\begin{array}{l}\text { AGR water reuse } \\
\text { potential }\end{array}$ & $\begin{array}{l}\text { Wastewater recycling } \\
\text { for agriculture (\%) }\end{array}$ & $\begin{array}{l}\text { Classification } \\
\text { (output var.) }\end{array}$ \\
\hline Very-high & $>10$ & 5 \\
High & $>6.5$ and $\leq 10$ & 4 \\
Average & $>3.5$ and $\leq 6.5$ & 3 \\
Low & $>1$ and $\leq 3.5$ & 2 \\
Very-low & $\leq 1$ & 1 \\
No reuse & 0 & 0 \\
\hline
\end{tabular}

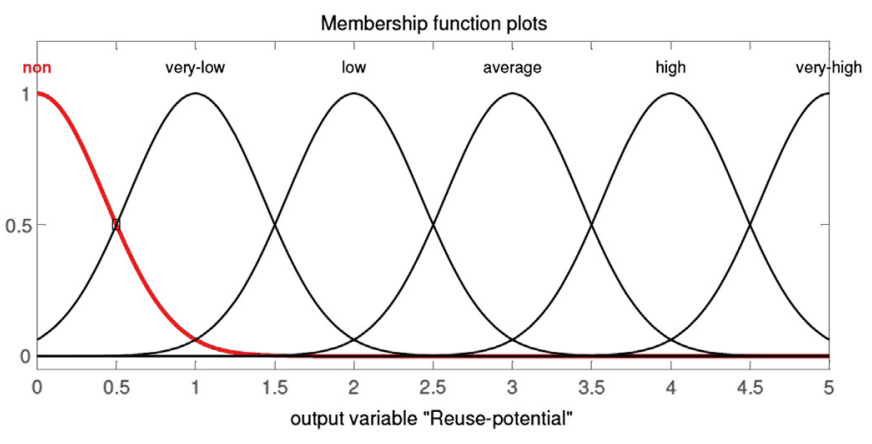

Fig. 7. Membership function of output variable Reuse-potential.

municipal water supply for 283 days) (Suzuki et al., 2003), although some cities exhibit low drought persistence (long term drought severity index), which lowers the simulation value of the urban potential water reuse FIS.

Despite the scarcity, many cities are not allowed to reclaim water owing to restrictions imposed by local water policies and worries about the risk to human health. Much research has been carried out and many guidelines have been published on water quality and on procedures for urban water reuse, but it has taken some countries a long time to draft policy and procedure documents, operations and maintenance plans, user agreements, design standards, and training and public information programs. Dallas (USA) took five years to take place its first reuse project. The city completed its "Recycled Water Implementation Plan" in 2005 (DWU, 2005) and in 2010 saw the start of urban reuse projects for golf course irrigation (Region C Water Planning Group, 2011). Water reuse can also involve court cases that impact on future reclamation. In March 1998 the United States Bureau of Reclamation set out to seek approval for an application to appropriate 43.78 million $\mathrm{m}^{3}$ per year of sewage effluent in Salt Lake Valley (Utah), but after six years there was no decision, due to a disagreement over water rights interpretations (UDWR, 2005).

Despite some imprecision between classification and simulation data for agricultural and urban water reuse potential FIS, it was possible to find whether the cities have water reuse potential, or

Table 7

Fuzzy Inference System rules for agricultural reuse potential.

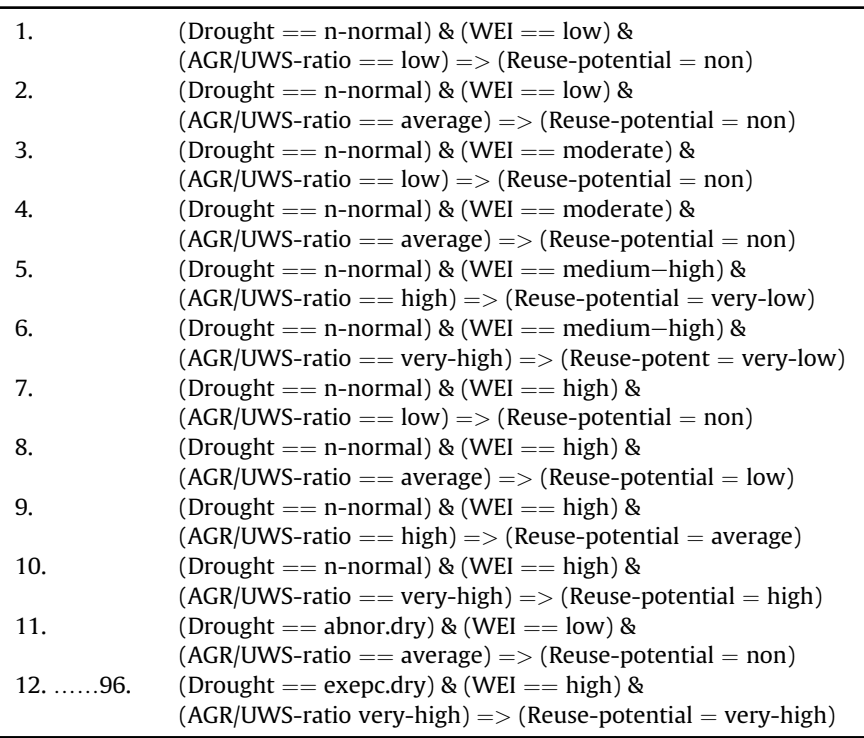




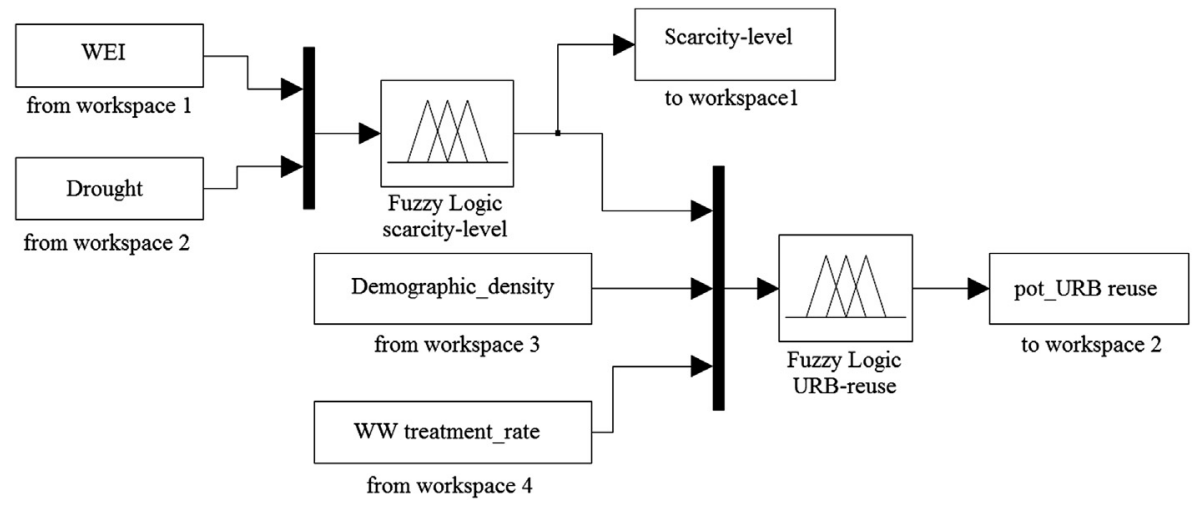

Fig. 8. Urban reuse potential data processing model.

Table 8

Scarcity-level classification.

\begin{tabular}{ll}
\hline Scarcity-level & Classification \\
\hline Very-high & 8 to 10 \\
High & 6 to 8.99 \\
Average & 4 to 5.99 \\
Low & 2 to 3.99 \\
Very-low & 0 to 1.99 \\
\hline
\end{tabular}

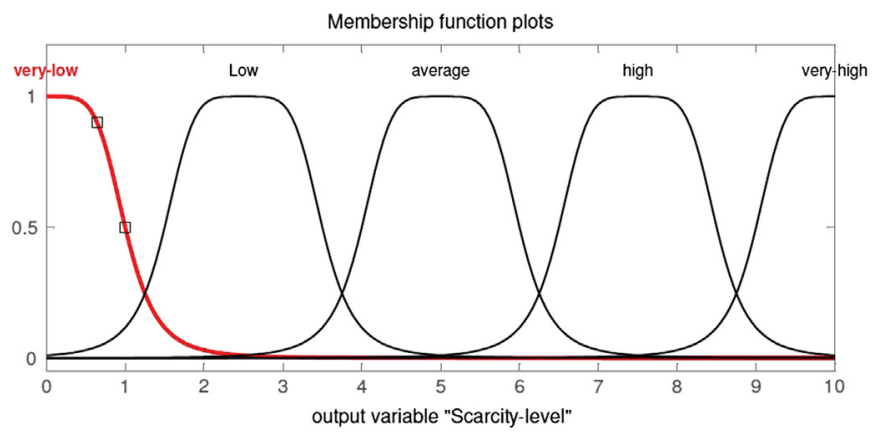

Fig. 9. Membership function of output scarcity-level variable.

not. The approach considered to model the water reuse potential indicated that some variables can give a warning to decision makers about the risks of water shortage and the consequent alternative water supply necessities. The decision surfaces of agricultural FIS rules indicate that the highest water reuse potential is verified for extremely and exceptionally drought events (values between 6 and 10) in regions with WEI above 25\% (Fig. 14a). For low droughts the WEI could affect the water supply when it reaches $45 \%$ or more. AGR/UWS-ratio is the last representative feature for the considered model. For instance, it is observed the greater influence of drought index in the relation between AGR/UWS-ratio and drought (Fig. 14b). Water reuse potential is representative for highest AGR/UWS-ratio and WEI above 40\% (Fig. 13).

Table 9

Scarcity-level variables.

\begin{tabular}{ll}
\hline Scarcity-level & Variables \\
\hline High & 7 to 10 \\
Average & 5 to 6.99 \\
Low & 0 to 4.99 \\
\hline
\end{tabular}

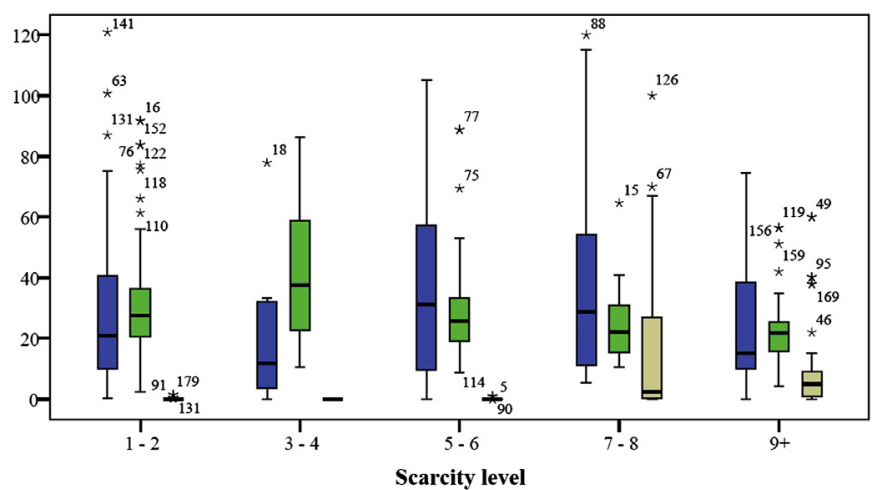

$\square$ Pop density (100peop/Km2) $\square$ Ratio water bill-income (10\%) $\square$ Urban recycling (\%)

Fig. 10. Evaluation of the influence of scarcity level on population density, ratio water bill - income and urban recycling.

Table 10

Demographic density variable.

\begin{tabular}{ll}
\hline Demographic density & Variables $\left(\mathrm{pop} / \mathrm{Km}^{2}\right)$ \\
\hline High & $>500$ \\
Average & $300-500$ \\
Low & $100-300$ \\
Non & $<100$ \\
\hline
\end{tabular}

The decision surfaces of urban FIS rules show that the highest water reuse potential is verified for high scarcity (6-10), demographic density above 300 and WW treatment rate above $60 \%$ (Fig. 14)

It is expected that the model could be useful for decision making in order to estimate future water reuse potential using new datasets despite the eventual need of model adaptation considering local factors that drive water scarcity. Water resources management entities and some others municipalities' authorities would be the key stakeholders for this system. Others models or tools could be used to create an inference system considering the model

Table 11

Wastewater treatment rate variable.

\begin{tabular}{ll}
\hline Wastewater treatment rate & Variables (\%) \\
\hline High & $>60$ \\
Average & $30-60$ \\
Low & $<30$ \\
\hline
\end{tabular}


Table 12

Urban water reuse potential classification.

\begin{tabular}{lll}
\hline $\begin{array}{l}\text { Urban reuse } \\
\text { potential }\end{array}$ & $\begin{array}{l}\text { Urban wastewater } \\
\text { recycling }(\%)\end{array}$ & $\begin{array}{l}\text { Classification } \\
\text { output variable }\end{array}$ \\
\hline Very-high & $>6$ & 5 \\
High & $>3.0$ and $\leq 6$ & 4 \\
Average & $>0.5$ and $\leq 3.0$ & 3 \\
Low & $>0.1$ and $\leq 0.5$ & 2 \\
Very-low & $\leq 0.1$ & 1 \\
No reuse & 0 & 0 \\
\hline
\end{tabular}

conception. For instance, the Bayesian network (BBN) is also used by researchers (Kjrćulff and Madsen, 2013) as alternative to fuzzy logic rule-based systems, so, BBN could be used in future work to compare results. It is also recommended that future work should develop a water reuse potential system for a smaller scope in order to use local features to identify water reuse potential more accurately. It was observed that the uncertain values between variables, adjustment of variables, inaccurate data and evaluation errors contribute to discrepancies between classification and simulation data.

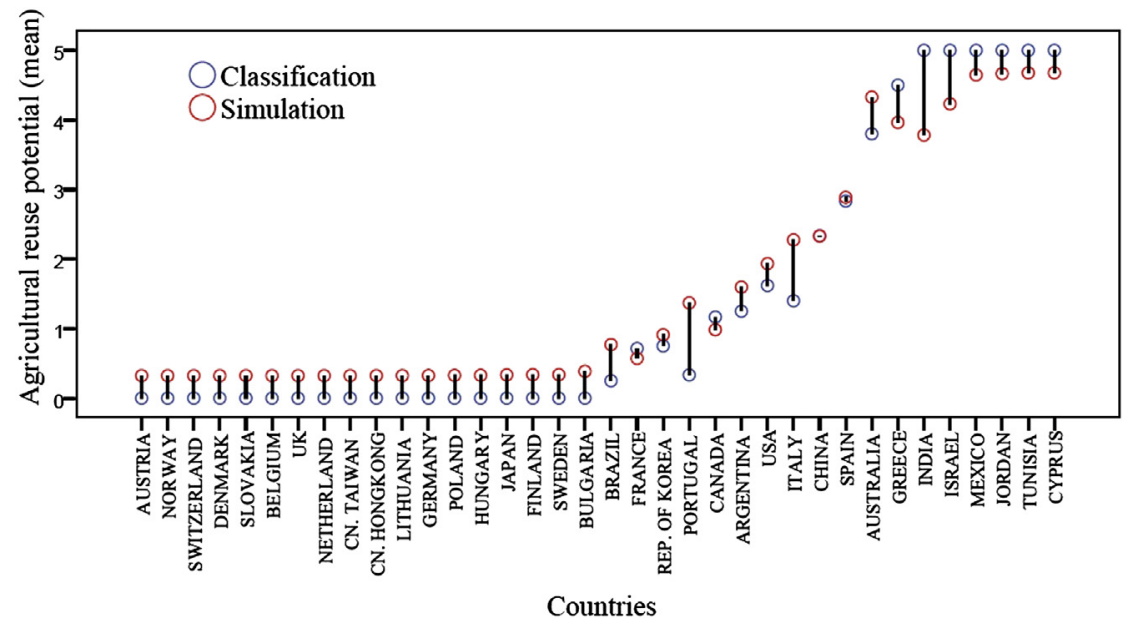

Fig. 11. Results of FIS agricultural water reuse potential for 155 regions by country.

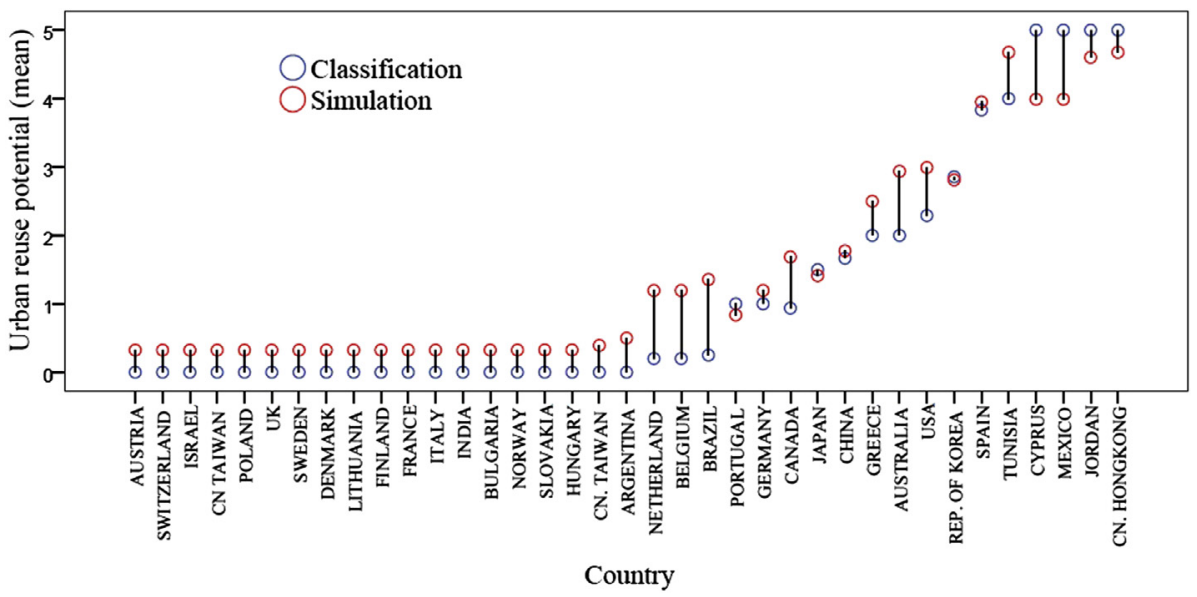

Fig. 12. Results of FIS urban water reuse potential for the 183 cities by country.
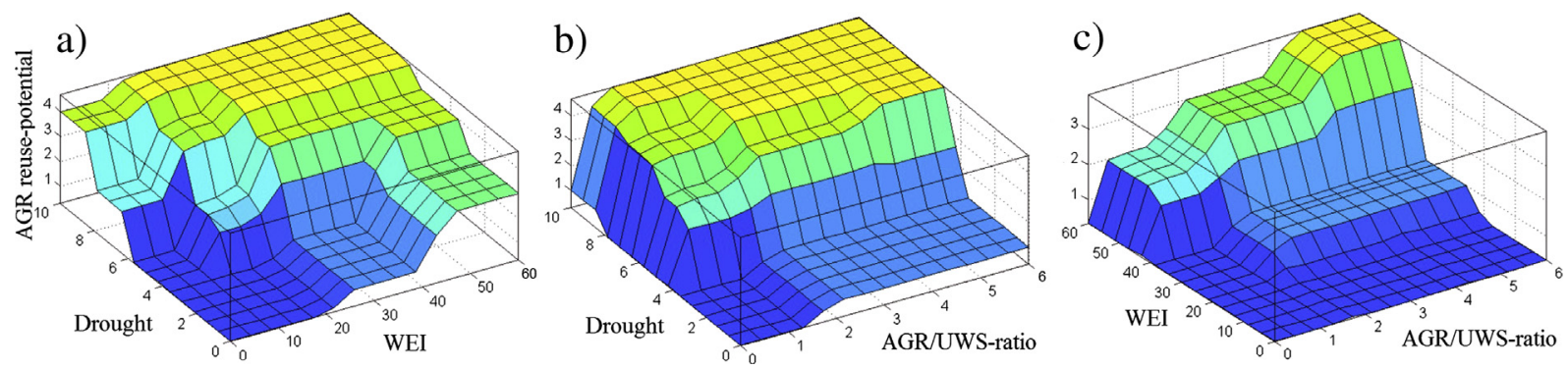

Fig. 13. Decision surface for agricultural water reuse potential: a) WEI and drought; b) AGR/UWS-ratio and drought; c) WEI and AGR/UWS-ratio. 

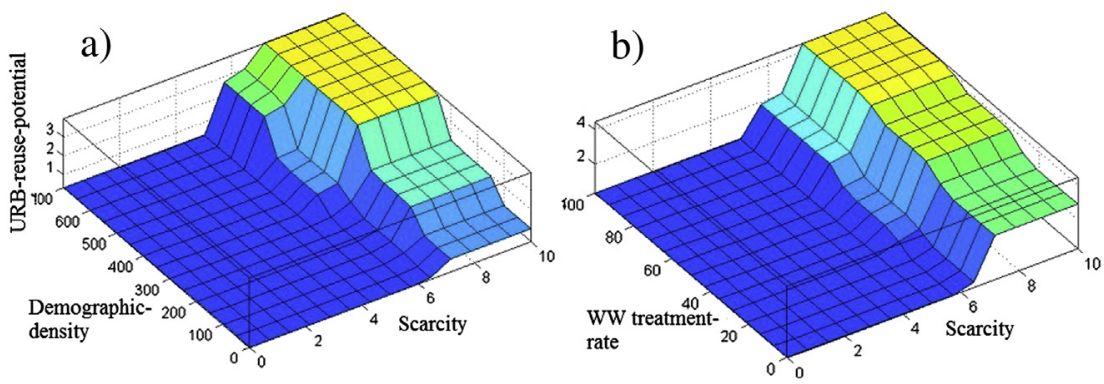

Fig. 14. Decision surface for urban water reuse potential: a) demographic density and scarcity; b) WW treatment rate and scarcity.

\section{Conclusions}

The development of a new decision tool that sets out the water availability trends and identify the alternative water resources necessities may be helpful for decision makers in regions with scarcity problems. This study suggests that "water reuse potential" is a good indicator to support decision-making with respect to alternative water supplies resources necessities. Information on water reuse potential is important because it can warn about future alternative water supply needs, and so predict water shortages. The complexities of the environment define the features needed to determine suitable simulation data. Feature such as, drought, water exploitation, water uses and wastewater treatment rate are considered relevant to the perceived need for reuse. The model built for agricultural and urban water reuse potential take into account a dataset of 155 regions and 185 cities around the world. The information provided by dataset was useful to arrange the features' variables under FIS membership functions. The decision surface resulting of the FIS rules indicated that the drought index is the most representative feature for agricultural water reuse potential. On the other hand, it is estimated that WEI is more related with urban water reuse potential. Other features, although less representatives, allow adjusting the model in order to simulate the classification data. The results have demonstrated that it is possible to identify the water reuse potential through a fuzzy inference system tool. However, other tool can be used and tested in future works, such as BBN. The model developed can be adapted considering local characteristics in order to help decisions makers about future water reuse necessities. The results of this work also promote the discussion of the water supply challenges considering climate change scenarios.

\section{Acknowledgments}

This work is supported by the Foundation for Science and Technology (FCT) under PhD grant SFRH/BD/66277/2009.

\section{Appendix A. Supplementary data}

Supplementary data related to this article can be found at http:// dx.doi.org/10.1016/j.jenvman.2013.06.048.

\section{References}

AECOM and NRC, 2009. National Water and Wastewater Benchmarking Initiative 2009 Public Report (online). Canada Government. Available from: <http://www. nationalbenchmarking.ca/public/docs/Public Report 2009.pdf $>$ (accessed 06.09.12.).

AQUASTAT/FAO, 2010. Water Withdrawal by Sector (online). FAO's Information System on Water and Agriculture. Available from: <http://www.fao.org/nr/ water/aquastat/data/query/index.html?lang=en $>$ (accessed 14.09.12.).
AQUASTAT/FAO, 2012. Water Uses (online). FAO's Information System on Water and Agriculture. Available from: <http://www.fao.org/nr/water/aquastat/water_ use/index.stm $>$ (accessed 23.08.12.).

Bates, B.C., Kundzewicz, Z.W., Wu, S., Palutikof, J.P., 2008. Climate Change and Water. Technical Paper of the Intergovernmental Panel on Climate Change.

BMBS, 2006. Statistical Communique on the National Economic and Social Development of the City of Beijing in 2005 \& the 10th Five-year Plan Period (online). Beijing Municipal Bureau of Statistics. Available from: <http://www.bjstats.gov. cn/esite/tjgb/200611/t20061122_77078.html> (accessed 20.09.12.).

Brown, A., Matlock, M., 2011. A Review of Water Scarcity Indices and Methodologies. University of Arkansas. The Sustainability Consortium, p. 21.

CAGECE, 2010. Consumo de água no Ceará cresce em $2009:$ : Notícias JusBrasil (online). Available from: < http://governo-ce.jusbrasil.com.br/politica/4559966/ consumo-de-agua-no-ceara-cresce-em-2009> (accessed 17.09.12.).

CBS, 2011. Israel in Figures (online). Central Bureau of Statistics. Available from: <http://www.cbs.gov.il/www/publications/isr_in_n11e.pdf > (accessed 17.09.12.).

Conte, G., 1999. Water Resources in Italy. Zer0-M (Sustainable Concepts Towards a Zero Outflow Municipality) and Associazione Ambiente e Lavoro Toscana ONLUS, Venice - Italy, p. 4.

CPHEEO, 2005. Status of Water Supply, Sanitation and Solid Waste Management in Urban Areas. National Institute of Urban Affairs. Central Public Health and Environmental Engineering Organisation, New Delhi - India, p. 191.

Dai, A., 2011. Drought under global warming: a review. WIREs Climate Change 2 (1), 45-65.

DANVA, 2011. Vand i tal. DANVA benchmarking 2011-procesbenchmarking og statistik (online). DANVA - Dansk Vand-og. Available from: <http://www.e-pages. dk/danva/97/fullpdf/full5048cf4498752.pdf $>$ (accessed 6.10.12.).

Direction de Agricultura, 2006. MinAgri - Argentina (online). Riego en Argentina Distribución del área regada a escala Provincial y Departamental. Available from: <http://64.76.123.202/site/agricultura/agua_y_suelos/03-riego/> (accessed 28.11.12.).

DWU, 2005. Dallas. Recycled Water Implementation Plan, vol. 1, p. 273.

EEA, 2010. Water Exploitation Index - towards a Regionalised Approach (online). European Environment Agency (EEA). Available from: <http://www.eea. europa.eu/data-and-maps/figures/water-exploitation-index-2014-towards/water-exploitation-index-2014-towards $>$ (accessed 19.09.12.).

Environment Canada, 2010. Municipal Water Use Data (online). Environment Canada - Water - Data and Publications. Available from: <http://www.ec.gc.ca/ eau-water/default.asp?lang=En\&n=ED0E12D7-1\#wateruse $>$ (accessed 17.09.12.).

Environment Canada, 2011. Environmental Indicators - Water Availability in Canada (online). Available from: <http://www.ec.gc.ca/indicateurs-indicators/default asp?lang $=$ en\&n=1B1433B4-6 $>$ (accessed 19.09.12.).

Eurostat statistics, 2007. Water Use by NUTS 2 Regions - Mio M3" and "Total Fresh Water Abstraction. European Commission (online) Available from: $<$ http://epp. eurostat.ec.europa.eu/portal/page/portal/statistics/search_database $>$ (accessed 17.09.12.).

Exall, K., Marsalek, J., Schaefer, K., 2004. A review of water reuse and recycling, with reference to Canadian practice and potential: 1 . Incentives and Implementation. Water Quality Research Journal of Canada 39 (1), 1-12.

GeoSpatial Solutions, 2005. Drought Hazard Frequency 2006 (CHRR). ISCIENCES, L.L.C (online) Available from: <http://geoserver.isciences.com:8080/geonetwork/srv/ en/metadata.show? $\mathrm{id}=285 \&$ currTab $=$ simple $>$ (accessed 19.09.12.).

Grail Research, 2009. Water - the India Story (online) Available from: <http:// www.grailresearch.com/pdf/ContenPodsPdf/Water-The_India_Story.pdf > (accessed 17.09.12.).

Hayes, M.]., 1999. Drought Indices. National Drought Mitigation Center (on line) Available from: < http://www.civil.utah.edu/ cv5450/swsi/indices.htm $>$ (accessed 17.09.12.).

Hermanowicz, S.W., 2006. Is Scarcity a Real Driver for Water Reuse? University of California (online) Available from: < http://www.ce.berkeley.edu/ $\sim$ hermanowicz/other/Hermanowicz reuse driverpdf $>$ (accessed 06.09.12).

Hyde, K.M., Maier, H.R., Colby, C.B., 2005. A distance-based uncertainty analysis approach to multi-criteria decision analysis for water resource decision making. Journal of Environmental Management 77 (4), 278-290.

INDEC, 2010. Censo Nacional de Población, Hogares y Viviendas 2010: Densidad de población por provincia (mapas). Instituto Geográfico Nacional (IGN) (online) Available from: < http://www.sig.indec.gov.ar/censo2010/> (accessed 17.09.12.). 
INE, 2010. Encuesta sobre el suministro y saneamiento del agua. Año 2010-Recogida y tratamiento de las aguas residuales por comunidades y ciudades autónomas. Instituto Nacional de Estadística. (National Statistics Institute) (online) Available from: <http://www.ine.es/jaxi/tabla.do?path=/t26/p067/p01/a2010/10/\&file=01005.px\& type $=$ pcaxis $\& \mathrm{~L}=0>$ (accessed 21.09.12.).

INEbase, 2010. Estadísticas sobre medio ambiente. Instituto Nacional de Estadística (online) Available from: <http://www.ine.es/jaxi/tabla.do $>$ (accessed 18.09.12.).

IPCC, 2012. Managing the Risks of Extreme Events and Disasters to Advance Climate Change Adaptation. A Special Report of Working Groups I and II of the Intergovernmental Panel on Climate Change. Text. Cambridge University Press, Cambridge, UK, and New York, NY, USA, p. 582.

ISTAT, 2005. Statistiche ambientali. Istat - Direzione centrale del censimento della popolazione, territorio e ambiente - Progetto metodologie e statistiche ambientali, Roma, p. 582.

ISTAT, 2006. Water Resources Assessment and Water Use in Agriculture. Roma, p. 198.

IWA, 2008. Water Reuse: an International Survey of Current Practice, Issues and Needs. IWA Publishing, London, pp. 373-558.

Joksimovic, D., Savic, D.A., Walters, G.A., Bixio, D., Katsoufidou, K., Yiantsios, S.G., 2008. Development and validation of system design principles for water reuse systems. Desalination 218 (1-3), 142-153.

Kjrćulff, U.B., Madsen, A.L., 2013. Bayesian Networks and Influence Diagrams: a Guide to Construction and Analysis (Google EBook). Springer, p. 382

Lima, J.E.F.W., Ferreira, R.S.A., Christofidis, D., 2000. O uso da irrigação no Brasil. EMBRAPA - Empresa Brasileira de Pesquisa Agropecuária (online) Available from: $<$ http://ag20. cnptia.embrapa.br/Repositorio/irrigacao_000fl7vsa7f02wyiv80ispcrr5frxoq4.pdf> (accessed 19.10.12.)

Liu, K., 2009. Beijing Steps up Its Commitment to 100\% Water Reuse by 2013. Global Water Intelligence (online) Available from: <http://www.globalwaterintel.com/ archive/10/4/general/beijing-steps-up-its-commitment-to-100-water-reuseby-2013.html $>$ (accessed 20.09.12.).

Ludwig, O., Schnitman, L., Lepikson, H., 2004. Uma Arquitetura Neural Híbrida para Extracão de Regras Nebulosas. IEEE Latin America Transactions 2 (2), 6.

Maldonado, V.M., Rubio Arias, H.O., Quintana, R., Saucedo, R.A., Gutierrez, M., Ortega, J.A., Nevarez, G.V., 2008. Heavy metal content in soils under different wastewater irrigation Patterns in Chihuahua, Mexico. International Journal of Environmental Research and Public Health 5 (5), 441-449.

Mapanda, F., Mangwayana, E.N., Nyamangara, J., Giller, K.E., 2005. The effect of longterm irrigation using wastewater on heavy metal contents of soils under vegetables in Harare, Zimbabwe. Agriculture, Ecosystems \& Environment 107 (2-3), 151-165.

Maplecroft, 2000. Water Stress (Pressure on Water Resources). Randamaps (online) Available from: <http://randamaps.maplecroft.com/?language $=$ en\&lat $=51$. $517 \&$ lon $=-0.138>$ (accessed 19.09.12.).

Maplecroft, 2012. Water Stress Index Map 2012. ReliefWeb (online) Available from: $<$ http://reliefweb.int/sites/reliefweb.int/files/resources/map_2103.pdf $>$ (accessed 19.09.12.).

Monte, H.M., 2010. Water Reuse in Portugal: Regulations and Practice (online). Available from: < http://www.asersagua.es/publicaciones/1_2_HMARECOS ASERSA_1CONF_INTERN.pdf $>$ (accessed 21.09.12.).

OECD, 2003. Water: Performance and Challenges in OECD Countries. Organisation for Economic Co-operation and Development (online) Available from: <http:// www.oecd.org/environment/environmentalcountryreviews/2498050.pdf > (accessed 29.08.12.)

Ohgaki, S., Takizawa, S., Kataoka, Y., Kuyama, T., Herath, G., Hara, K., Kathiwada, N.R., Moon, H.-J., 2007. Sustainable Groundwater Management in Asian Cities. Kanagawa - Japan, p. 179.

Park, S., 2010. Water reuse policy in Korea and technical cases (online). In: Ministerial Conference on Environment and Development in Asia and the Pacific (MCED). United Nations - ESCAP. Available from: <http://www.unescap.org/mced6/side_ events/documents/eeei/Sangwon Park-KU.pdf $>$ (accessed 21.09.12.)

Peasey, A., Blumenthal, U., Mara, D., Ruiz-Palacios, G., 2000. A Review of Policy and Standards for Wastewater Reuse in Agriculture: a Latin American Perspective. Task No: 68 Part II [online]. London School of Hygiene \& Tropical Medicine. WEDC, Loughborough University. Available from: <http://www.lboro.ac.uk/well/ resources/well-studies/full-reports-pdf/task0068ii.pdf > (accessed 20.09.12.)

Pink, B., 2009. Water Account, Australia, 2008-09. Water Supply and Use (online). Australian Bureau of Statistics. Available from: <http://www.abs.gov.au/ AUSSTATS/abs@.nsf/DetailsPage/4610.02008-09?OpenDocument> (accessed 27.08.12.).

Probe International Beijing Group, 2008. Beijing Water Crisis 1949-2008 (online) Available from: < http://www.chinaheritagequarterly.org/016/_docs/BeijingWa terCrisis1949-2008.pdf $>$ (accessed 17.09.12.).

Raddad, K., 2005. Water supply and water use statistics in Jordan. In: IWG-Env, International Work Session on Water Statistics. United Nations Statistics Division, Vienna, p. 7.
Region C Water Planning Group, 2011. Region C Water Plan (online). Freese and Nichols, Inc. Alan Plummer Associates, Inc. CP\&Y, Inc. Cooksey Communications, Inc. Available from: < http://www.twdb.state.tx.us/waterplanning/rwp/plans/ 2011/C/Region_C_2011_RWPV1.pdf > (accessed 11.09.12.).

Schaefer, K., Exall, K., Marsalek, J., 2004. Water reuse and recycling in Canada: a status and needs assessment. Canadian Water Resources Journal 29 (3), 195-208.

Schrier, G. Van Der, Briffa, K.R., Jones, P.D., Osborn, T.J., 2005. Summer moisture variability across Europe. Journal of Climate 19, 2818-2832.

Shepard, R.B., 2005. Quantifying Environmental Impact Assessments Using Fuzzy Logic. Springer Science+Business Media, Inc, New York, p. 262.

SRH/MMA - Brasil, 2006. Plano Nacional de Recursos Hídricos (online). Secretaria de Recursos Hídricos - Ministério do meio Ambiente. Available from: <http:// www.integracao.gov.br/c/document_library/get_file?uuid=c37feae3-81694049-900b-e8160661f541\&groupId=66920> (accessed 19.09.12.).

Statistics Canada, 2010. Agricultural Water Use in Canada: Table 5-1 - Irrigation Volume by Month, 2010 - Province or Region (online). Statistics Canada. Available from: <http://www.statcan.gc.ca/pub/16-402-x/2011001/t008-eng. htm $>$ (accessed 19.09.12.).

Suzuki, Y., Ogoshi, M., Yamagata, H., Ozaki, M., Asano, T., 2003. Large-area and Onsite Reuse in Japan, p. 16. Ibaraki.

Tajima, A., Minamigama, H., Nakajima, H., 2002. Present State of the Treated Wastewater Reuse in Japan. National Institute for Land and Infraestruture Management (NILIM), Wastewater and Sludge Division, Ibaraki, Japan, p. 19.

The World Bank, 2009. Water in the Arab World: Management Perspectives and Innovations. Washington, DC, p. 554

The World's Water, 2010. Freshwater Withdrawal, by Country and Sector (2010 Update)/Total Renewable Freshwater Supply, by Country (2010 Update) (online). Pacific Institute. Available from: <http://www.worldwater.org/data. html $>$ (accessed 19.09.12.)

Tkach, R.J., Simonovic, S.P., 1997. A new approach to multi-criteria decision making in water resources. Journal of Geographic Information and Decision Analysis 1 (1), 25-43.

Triantaphyllou, E., Shu, B., Sanchez, S.N., Ray, T., 1998. Multi-criteria decision making: an operations research approach. Electronics 15, 175-186.

Tsagarakis, K.P., Dialynas, G.E., Angelakis, A.N., 2004. Water resources management in Crete (Greece) including water recycling and reuse and proposed quality criteria. Elsevier. Agricultural Water Management 66, 35-47.

UDWR, 2005. Water Reuse in Utah (online). Utah Division of Water Resources. Available from: <http://www.water.utah.gov/WaterReuse/WaterReuseAA.pdf > (accessed 09.09.12.).

USEPA, 2004. Guidelines for Water Reuse (online). U.S. Environmental Protection Agency. Available from: <http://www.epa.gov/nrmrl/wswrd/dw/smallsystems pubs/625r04108.pdf $>$ (accessed 18.09.12.).

USGS, 1995. Comparisons of Average Consumptive Use and Renewable Water Supply for the 21 Water-resources Regions of the United States, Puerto Rico, and U.S. Virgin Islands (online). U.S. Geological Survey. Available from: <http:// water.usgs.gov/watuse/misc/consuse-renewable.html $>$ (accessed 19.09.12.).

USGS, 2000. Estimated Use of Water in the United States in 2000 (online). United States Geological Survey. Available from: <http://pubs.usgs.gov/circ/2004/ circ1268/htdocs/table02.html > (accessed 19.09.12.)

Walton, B., 2011. The Price of Water 2011: Prices Rise an Average of 9 Percent in Major U.S. Cities (online). Circle of Blue. Available from: <http://www. circleofblue.org/waternews/2011/world/the-price-of-water-2011-prices-risean-average-of-9-percent-in-major-u-s-cities/> (accessed 23.07.12.)

WI, 2006. Urban Wastewater-livelihoolds, Health and Environmental Impacts in India (online). Winrock International India, Institute for Studies and Transformations, Department of Economics, EcoFriends, Spatial Decisions and YUVA -Youth for Unity \& Voluntary Action. Available from: < http://www.iwmi.cgiar. org/assessment/files_new/research_projects/Urban Wastewater-Full_Report. pdf $>$ (accessed 20.09.12.)

Wintgens, T., Hochstrat, R., 2006. Report on Integrated Water Reuse Concepts - Integrated Concepts for Reuse of Upgraded Wastewater (online). AQUAREC. Available from: $<$ http://www.susana.org/lang-en/library?view =ccbktypeitem\&type $=2 \& i d=551>$ (accessed 24.09.12.)

World Water Assessment Programme, 2009. The United Nations World Wate Development Report 3: Water in a Changing World, third ed. UNESCO, and London: Earthscan, Paris, p. 349.

WSPS, 2004. Planning Jordan's Water Future (online). Water Sector Planning Support (WSPS) Project, Ministry of Water and Irrigation. Available from: <http:// www.emwis.org/countries/fol749974/country045975/PDF/planning-jordanwater $>$ (accessed 20.09.12.).

Zadeh, L.A., 1965. Fuzzy sets. Information and Control 8, 338-353.

Zarghami, M., Abrishamchi, A., Ardakanian, R., 2007. Multi-criteria decision making for integrated urban water management. Water Resources Management 22 (8), 1017-1029. 